\title{
Structural, Level and Typological Properties of the Psychological Aspect of Professional Responsibility of Pharmaceutical Industry Workers
}

\author{
Natalia V. Lukyanchenko* and Irina A. Tkachenko \\ Siberian State Technological University \\ 82 Mira, Krasnoyarsk, 660049, Russia
}

Received 17.12.2014, received in revised form 20.01.2015, accepted 30.01.2015

The present article determines the timeliness of studying the psychological aspect of professional responsibility. It outlines its structural components: functional component including personal characteristics for actualization of the responsibility and reflective-axiological component, which stands for the understanding of responsibility and its subjective value basis by the person. It presents the results of the research, carried out on the basis of pharmaceutical industry. The research describes the following levels of professional responsibility development: operational, social and personal. It states that the formedness of the personal level of professional responsibility development decreases the manifestation of the features, distinctive on the operational and social levels. The present article outlines the typological groups of respondents, different from each other in the distinctive features of the psychological aspect of professional responsibility. It demonstrates that the highest functional indicators of professional responsibility are manifested by the group with the personal level of professional responsibility development, while the lowest belong to those with the operational level.

Keywords: professional responsibility, functional, reflective-axiological components of the psychological aspect of responsibility, emotional self-regulation, volitional self-control, internality, development levels of professional responsibility.

Research area: pedagogy.

\section{Introduction}

There is no doubt that in the modern society with its sophisticated production technologies, high level of labour differentiation and close bonds between the activities of various fields, the professional responsibility problem is highly urgent. It refers to the sphere of the so-called "human factor" playing the essential role in providing high efficiency and safety of production and the produced commodities.
Being one of the major components of the life activity of modern person, professional activity is a specialized form of labour. The key feature of labour is its purpose, which is to create a socially useful product satisfying the material or spiritual needs of the society. As pointed out by S.L. Rubinstein, being intended for achievement of a certain result, labour needs planning and control, a priori including, therefore, a set of certain obligations and requiring inner discipline

(C) Siberian Federal University. All rights reserved

* Corresponding author E-mail address: Luk.nv@mail.ru 
[23]. According to V.D. Shadrikov, despite the fact that the social significance of activity and its personal meaning may not match, the person shall realize the consequences of their actions for the society, which assumes the presence of responsibility [28].

\section{Discussion}

A.P. Chirkov remarks that responsibility is a phenomenon that objectively exists as the essential manifestation of order in social relations; it reflects the objective need for coordination of social communication subjects' behaviour [27]. It is the social significance of the professional activity results that determines the importance of the responsibility phenomenon. Together with that, as a unique phenomenon of human nature, responsibility is described by the fact that one answers for his deeds not only to some external institutions, but also to himself. As a result of human evolution, responsibility now appears as an internal self-control mechanism.

In the psychological aspect, responsibility is a form of self-regulation and self-determination, based on the subjective readiness of a person to answer for his own deeds and their consequences [3]. Various issues of the responsibility problem have been studied in works by such representatives of psychological science, as V.S. Ageev [1], S.V. Bykov [8], O.A. Gulevich [10], L.I. Dementiy [11], V.E. Kupchenko [15], K. Muzdybaev [17], A.A. Nalchadzhian [20], V.P. Priadein [22], V.G. Sakharova [24], H. Aguinis [30], J. B. Fuller [33], V. L. Hamilton [37], K. Hester, [33], K. Helkama, [34], F. G. Kaiser [35], H. C. Kelman [37], J. Kennett [37], D. F. Marks [38], L. E. Marler [33], R. May [19], T. A. Shimoda [35].

Definition of the psychological core of responsibility, analysis of conceptual and empirical studies of the mentioned authors allow us to regard the following personal properties as the functional characteristics of the psychological aspect of responsibility: realization of the social meaning of one's deeds, ability to perceive oneself as the cause factor of the current situation, emotional and volitional self-regulation.

Studies of the psychological aspect of responsibility from the point of view of the levels of development and forming of such appear important in the present context. Thus, M. Ostasheva discovers the following sequence in the process of responsibility formation: responsibility for oneself, responsibility for another person, personal responsibility of a society member [21]. According to K. Helkama, responsibility is formed in three phases with the appropriate level characteristics: 1) autonomous subjective responsibility; 2) responsibility as a social obligation; 3) morality principles based responsibility [34].

Generalized results of the analysis of theoretical and methodological postulates on the psychological nature of responsibility form the basis for outlining two components of responsibility: functional (complex of personal characteristics ensuring actualization of responsibility) and reflective-axiological (realization of responsibility and its subjective value basis by the person).

Professional responsibility as such was studied in works by D.B. Antipov [2], T.V. Belykh [12], Bodrov [4], O.A. Bol'shakova [5], I.E. Bulatnikov [7], L.I. Dementiy [11], N.F. Zhelaevskaia [13], A.G. Lutsenko [4], L. Muzdybaev [16], M.V. Mukonina [18], T.P. Emel'ianova [12], M.S. Solodkaia [25], O.N. Shaldybina [29], T.A. Brennan [31], N. M. Crystal [32]. The researchers emphasize the close bond between professional responsibility and integral features of the personality, causing the capacity of the labourer to satisfy the professional requirements and the readiness to provide a report on the achieved results. In the process of methodological analysis of the professional 
responsibility problem, M.S. Solodkaia remarks that it is based on personal freedom as a specific form of activity, the essential characteristics of which are awareness and consciousness [25].

Based on the analysis of opinions on the meaning of the term "professional responsibility, expressed by specialists in different fields, V.A. Bodrov and A.G. Lutsenko compiled a thesaurus of the related psychological features, classified into groups. The first group included the characteristics reflecting the relation of the person to labour, co-workers, and to himself in the process of activity. The second group united the traits of character: moral, volitional, emotional [4]. It is worth noticing that the groups of characteristics for professional responsibility, empirically outlined in the present research, refer to the components of responsibility (reflective-axiological, functional), determined on the basis of theoretical analysis of scientific literature.

Analysis of the professional responsibility problem as a whole demonstrates that the characteristics of its psychological aspect attract more and more of the researchers' attention. Along with that, development of proven psychological technologies for forming professional responsibility requires more data on the structural, level and typological peculiarities of such. For this reason, we conducted the present research on the basis of the industry where professional responsibility bears special significance.

\section{Methodological support and empirical base for the research}

The research was based on the pall of ninety seven employees of Limited Liability Company "Novosibkhimfarm" specializing in officinal medicines' production.

The methodological complex of the research includes methods for discovering the peculiarities of revealing the properties characterizing the psychologicalaspect of professional responsibility. The research of personal properties included into the functional component of professional responsibility was carried out with: method "Level of emotional intelligence by N. Hall"; method "Volitional self-control" by A.V. Zverkov and E.V. Eidman; social responsibility scale by L. Berkovits and K. Luttermen; method "Level of subjective control" by E.F. Bazhin and A.M. Etkind; questionnaire for studying the reflective-axiological component of professional responsibility.

Method "Level of emotional intelligence" [26] was introduced by N. Hall for revealing the capacity to understand the attitudes of a person represented in emotions, and to control the emotional sphere on the basis of the made decisions. It consists of five scales: emotional awareness, emotion management, self-motivation, empathy, recognition of other people's emotions.

Method "Volitional self-control" by A.V. Zverkov and E.V. Eidman [14] is designed for generalized assessment of the individual level of development of volitional regulation understood as the command of the person's own behaviour in different situations, the ability of the person to keep conscious control over their own deeds, states and incentives.

Social responsibility scale by L. Berkovits and K. Luttermen [9] aids assessing the inclination of a person to keep to a group of common rules, social norms, and role responsibilities.

Method "Level of subjective control" by E.F. Bazhin and A.M. Etkind [6] reveals the ability of the person to realize themselves as the cause for the present situation (internality), allows to determine the general level of internality and its distinctiveness in six spheres of the person's life: separately among achievements and fails, in family relations, in labour relations, in interpersonal relations and in the sphere of health. 
In the present research we studied the data of all scales except for family relations.

Individual peculiarities of understanding professional responsibility (reflectiveaxiological component of professional responsibility) by the respondents were revealed with the help of a questionnaire. The questions were intended to help the respondents to evaluate the level of professional responsibility in their industry and formulate their own understanding of professional responsibility. The key questions, the results of which were included into the mathematic processing, were the following: "What do you think professional responsibility is?", "What in your opinion influences the level of professional responsibility in your professional sphere?", "Name the features of a responsible worker in your field". First of all, the qualitative analysis of the questionnaire answers was conducted to outline the three types of answers which, in our opinion, may be regarded as characteristics of the responsibility formedness level.

The first level was called "operational" and included the answers where the basics of professional responsibility were limited to accurate performance of obligations under the instruction, following the schedule and hygiene of labour. The second level is "social". It included the interpretation of professional responsibility from the point of view of attention to the opinion of co-workers, wish to maintain friendly ambience within the staff, help exchange with co-workers and superiors, social assessment of labour. The third level is "personal", where professional responsibility is interpreted as subjective, as an ability to be guided by morality principles and mindsets, based on the responsibility for life and health of people. As a quantitative indicator, the frequency of characteristics of the mentioned levels in the respondents' answers to the questionnaire was regarded.
For the processing of the data obtained in the process of research, the following methods were used: rank correlation analysis with Spearman rank correlation coefficient, cluster analysis (with the approximate nearest neighbour method in Euclidean space), revealing significant differences with Mann-Whitney coefficient. The statistic data were calculated with Statgraphics Plus v.2.1. software.

\section{Results and discussion}

Table 1 presents the rank correlation analysis of interconnection of the indicators of the level characteristics of the reflective-axiological component of professional responsibility.

As understood from Table 1, the evidence of the personal level characteristics of professional responsibility is inversely proportional to that of the operational and social levels in the reflectiveaxiological aspect. In other words, the more the individual perceives himself as the source of his responsibility, and the more he acts in accordance with his moral and ethical standards, the less he relies on the norms imposed by the technological requirements of the production process, the attitude and opinion of other people.

Table 2 presents the results of the correlation analysis of interconnection between the functional characteristics of responsibility and level characteristics of the reflective-axiological aspect of professional responsibility.

The most distinctive tendency of the data presented in the Table is the multiple negative associations of the control locus indicators and the characteristics of the reflective-axiological aspect of professional responsibility referred to the operational level. This means that the respondents confident in their ability to influence the situation, are not inclined to limiting their professional responsibility to the "technological conformity" level. The positive associations of the evidence of the social level characteristics 
Table 1. Interconnection of the level characteristics of the reflective-axiological component of professional responsibility (according to the data received with "Professional Responsibility" questionnaire)

\begin{tabular}{|l|c|c|c|}
\hline \multicolumn{1}{|c|}{$\begin{array}{c}\text { Levels of formedness of } \\
\text { professional responsibility }\end{array}$} & Operational level & Social level & Personal level \\
\hline Operational level & & & $-0,44$ \\
\hline Social level & & & $-0,43$ \\
\hline Personal level & $-0,44$ & $-0,43$ & \\
\hline
\end{tabular}

0,29 under $\rho \leq 0,05$

0,50 under $\rho \leq 0,01$

Table 2. Interconnection between the indications of the functional and reflective-axiological components of the psychological aspect of professional responsibility

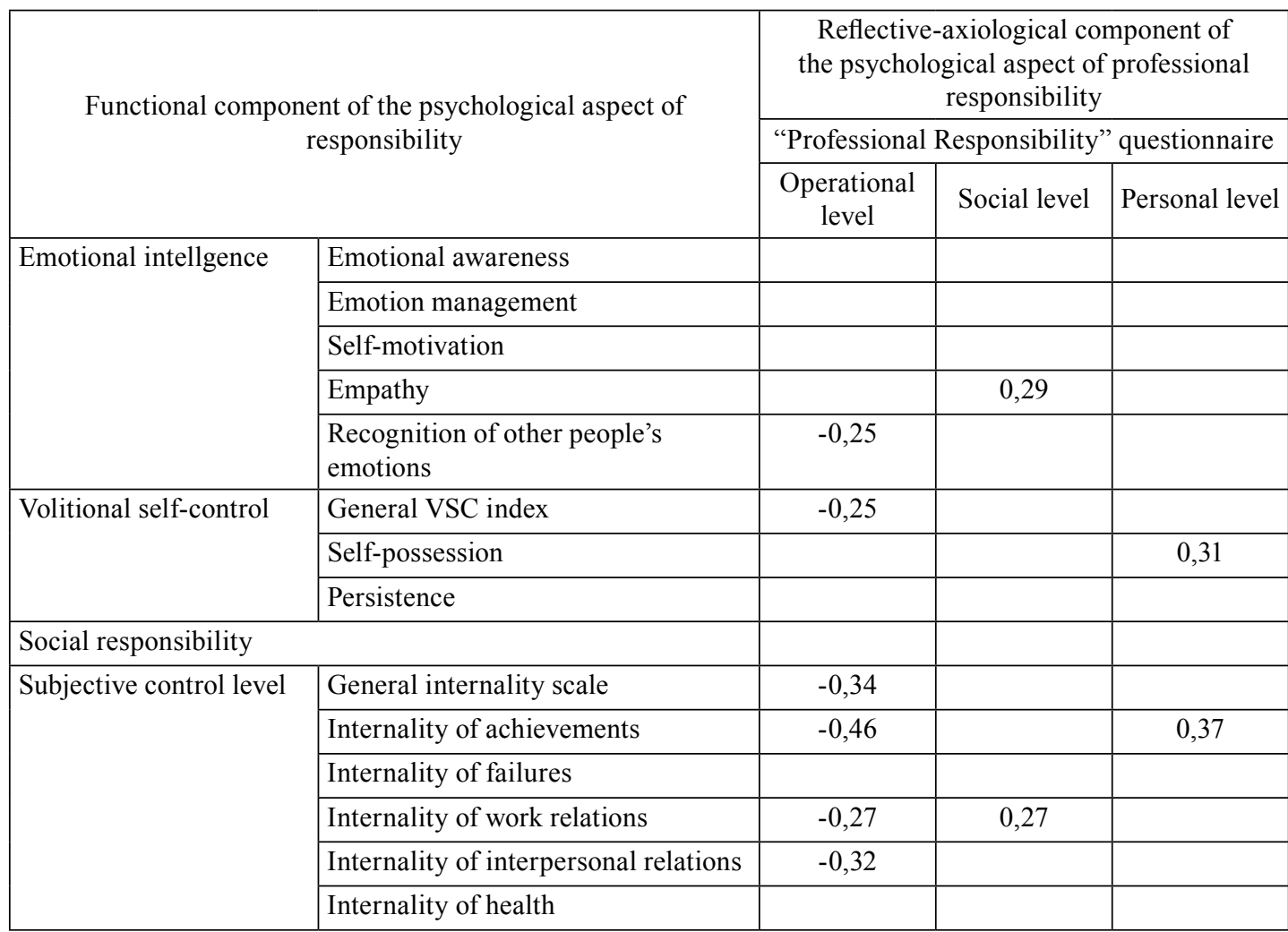

0,29 under $\rho \leq 0,05$

0,50 under $\rho \leq 0,01$

of professional responsibility with the empathy and internality indicators in the sphere of industrial relations look logical. The evidence of the personal level characteristics is positively associated with self-possession and internality of achievements.
The cluster analysis of the obtained data served as a base for dividing the respondents' into two groups with two subgroups in each.

The percentage of each group in the total volume of the sampling and peculiarities of the groups from the point of view of the level 
Table 3. Representativeness of characteristics of the reflective-axiological aspect of professional responsibility in cluster groups

\begin{tabular}{|l|c|c|c|c|}
\hline \multicolumn{1}{|c|}{ Group } & \multicolumn{2}{c|}{ Group 1 } & \multicolumn{2}{c|}{ Group 2} \\
\hline Subgroup & 1.1 & 1.2 & 2.1 & 2.2 \\
\hline Share in sampling ( \%) & $22 \%$ & $18 \%$ & $42 \%$ & $18 \%$ \\
\hline $\begin{array}{l}\text { Representativeness of level characteristics of } \\
\text { professional responsibility }\end{array}$ & operational & $\begin{array}{c}\text { operational } \\
\text { personal }\end{array}$ & $\begin{array}{c}\text { operational } \\
\text { social }\end{array}$ & personal \\
\hline
\end{tabular}

characteristics of the reflective-axiological aspect of professional responsibility are reflected in Table 3.

Subgroup 1.1 includes the respondents who characterize professional responsibility purely from the point of view of following technological norms (operational level). Representatives of subgroup 1.2 compiled their professional responsibility definition of operational level characteristics mostly, completing it with some personal level characteristics. In subgroup 1.2 professional responsibility was dominantly defined with the operational level characteristics, but they were also completed with some social level characteristics. As can be seen from Table 3, this subgroup is the largest among all the research samplings. Group 2.2 is to some extent unique as, unlike the other groups, the respondents included into this one define professional responsibility with exclusively personal definitions with no operational level characteristics involved.

Below the results of comparison of responsibility functional indicators in the mentioned cluster groups are demonstrated: mean values in Table 4 (in bold, the largest values of the subgroups, in underlined italics the smallest ones are indicated), and the specificity and trueness of relevant differences in Table 5.

Generalizing the comparative analysis data, we may characterize the outlined respondent groups as follows. The first one differs from the second one with the lower values under the majority of functional indicators of responsibility. Comparing the data on the respondents from the four outlined subgroups, we find the following.

Research participants from subgroup 1.1, who define responsibility in purely operational level characteristics, show the lowest values of the emotional management indicator, all volitional self-control indicators and subjective control level. This means that the respondents who believe that responsibility is limited to pedantic following the norms and requirements of the professional standard are less capable of seeing the consequences of their actions and regulating their activity on their own; they are worse at managing their emotional state than other participants of the research.

Respondents from subgroup 1.2, who include more of operational level characteristics with some addition of personal level ones into their definition of professional responsibility, also have low indicators of subjective control and emotional intelligence values associated with comprehension of other people's state. Together with these, the group demonstrates the highest values of persistence and general index of volitional self-control.

Representatives of subgroup 2.1, who define responsibility on the operational and social levels, demonstrate quite high values of functional characteristics of responsibility, but the highest ones they demonstrate in comparison 
Table 4. Means values of the functional characteristics of responsibility in the cluster group

\begin{tabular}{|c|c|c|c|c|c|c|c|}
\hline \multirow{2}{*}{ Comparison parameter } & \multirow{2}{*}{ Scale } & \multicolumn{6}{|c|}{ Peer groups } \\
\hline & & 1 & 2 & 1.1 & 1.2 & 2.1 & 2.2 \\
\hline \multirow[t]{5}{*}{ Emotional intelligence } & Emotional awareness & 8,3 & 11,8 & 11,1 & $\underline{4,8}$ & 11,7 & 12,25 \\
\hline & Emotion management & 5,7 & 6,5 & $\underline{4,6}$ & 7 & 5,1 & 9,5 \\
\hline & Self-motivation & 9,7 & 10,8 & 11,6 & $\underline{7,4}$ & 10,8 & 11 \\
\hline & Empathy & 8,1 & 10,9 & 11 & $\underline{4,4}$ & 11 & 10,8 \\
\hline & $\begin{array}{l}\text { Recognition of other people's } \\
\text { emotions }\end{array}$ & 5,6 & 9,2 & 8,4 & $\underline{2}$ & 8,5 & 10,9 \\
\hline \multirow[t]{3}{*}{ Volitional self-control } & General VSC index & 14,9 & 16,7 & $\underline{12,7}$ & 17,8 & 16,5 & 17,1 \\
\hline & Self-possession & 9,1 & 10,1 & $\underline{8,1}$ & 10,4 & 9,8 & 10,7 \\
\hline & Persistence & 10,5 & 16,1 & $\underline{9,5}$ & 11,8 & 10,9 & 11,3 \\
\hline \multicolumn{2}{|l|}{ Social responsibility } & 7,8 & 10,2 & 8,2 & 7,4 & 11,8 & $\underline{6,8}$ \\
\hline \multirow[t]{6}{*}{ Subjective control level } & General internality scale & 27,3 & 31,5 & $\underline{24,8}$ & 30,4 & 30,4 & 33,8 \\
\hline & Internality of achievements & 7,5 & 8,7 & $\underline{6,9}$ & 8,3 & 8 & 10,5 \\
\hline & Internality of failures & 7,1 & 8 & $\underline{6,3}$ & 8 & 7,9 & 8,3 \\
\hline & Internality of work relations & 6,2 & 7,5 & $\underline{5,9}$ & 6,6 & 7,5 & 7,5 \\
\hline & $\begin{array}{l}\text { Internality of interpersonal } \\
\text { relations }\end{array}$ & 2,1 & 2,7 & $\underline{1,9}$ & 2,3 & 2,4 & 3,3 \\
\hline & Internality of health & 1,8 & 2,6 & $\underline{1,4}$ & 2,4 & 2,6 & 2,6 \\
\hline
\end{tabular}

Table 5. Specificity and trueness of differences between cluster groups under different functional characteristics of responsibility

\begin{tabular}{|c|c|c|c|c|}
\hline \multirow{2}{*}{ Comparison parameter } & \multirow{2}{*}{ Scale } & \multicolumn{3}{|c|}{ Peer groups } \\
\hline & & $1-2$ & $1.1-1.2$ & $2.1-2.2$ \\
\hline \multirow[t]{5}{*}{ Emotional intelligence } & & $\begin{array}{c}<; \\
95 \%\end{array}$ & $>; 95 \%$ & \\
\hline & Emotional awareness & & & $<; 95 \%$ \\
\hline & Emotion management & & $>; 95 \%$ & \\
\hline & Self-motivation & $<; 95 \%$ & $>; 99 \%$ & \\
\hline & Empathy & $<; 95 \%$ & $>; 99 \%$ & $<; 90 \%$ \\
\hline \multirow[t]{3}{*}{ Volitional self-control } & Recognition of other people's emotions & & $<; 99 \%$ & \\
\hline & General VSC index & $<; 95 \%$ & $<; 99 \%$ & \\
\hline & Self-possession & & $<; 95 \%$ & \\
\hline & & Persistence & & >; $99 \%$ \\
\hline \multirow{7}{*}{$\begin{array}{l}\text { Social responsibility } \\
\text { Subjective control level }\end{array}$} & & $<; 99 \%$ & $<; 99 \%$ & $<; 95 \%$ \\
\hline & General internality scale & $<; 99 \%$ & $<; 95 \%$ & $<; 99 \%$ \\
\hline & Internality of achievements & $<; 90 \%$ & $<; 95 \%$ & $<; 95 \%$ \\
\hline & Internality of failures & $<; 99 \%$ & $<; 90 \%$ & \\
\hline & Internality of work relations & $<; 99 \%$ & & \\
\hline & Internality of interpersonal relations & $<; 95 \%$ & & $<; 95 \%$ \\
\hline & Internality of health & $<; 99 \%$ & $<; 95 \%$ & \\
\hline
\end{tabular}


with other respondents are the indicators of social responsibility and internality of work relations.

The highest values of the majority of functional characteristics' indicators of responsibility are shown by subgroup 2.2 , where the reflective-axiological component equals to the personal one. In this group the indicators of emotional intelligence, volitional control and subjective control level are high. The only low indicator (the lowest in comparison with other groups) is that of social responsibility. In other words, the representatives of this group do not consider professional responsibility as socially induced, related to an external standard or attitude, and even, to some extent, oppose responsibility to social regulation.

\section{Conclusions}

Drawing conclusions of the research, we may remark the following:

1. Professional responsibility problem is extremely urgent in modern industries.

2. The structure of the psychological aspect of professional responsibility may be considered in the characteristics of its functional and reflective-axiological components.
3. The research of the psychological aspect of the professional responsibility of pharmaceutical industry workers revealed that the formedness of the personal level of the professional responsibility development decreases the evidence of the subjacent levels, operational and social.

4. The level characteristics of the reflectiveaxiological component and the characteristics of the functional component of the psychological aspect of professional responsibility are interconnected. The evidence of the operational level characteristics is inversely proportional to the functional characteristics' indicators.

5. The research outlines the typological groups of respondents with different evidence of the level characteristics of professional responsibility. It should be noted that the group with the personal level of professional responsibility development demonstrates the highest indicators of functional characteristics, while the group with the operational characteristics shows the lowest ones. In the groups combining the operational level characteristics with the characteristics of social and personal level, the evidence of a narrow diapason of the functional characteristics of professional responsibility was noticed.

\section{References}

1. Ageev V.S. Atributsiia otvetstvennosti za uspekh ili neudachu gruppy v mezhgruppovom vzaimodeystvii [Attribution of Responsibility for the Success or Failure of a Group in Intergroup Relations] // Voprosy psikhologii, (6), 101-106, 1982.

2. Antipov D.V. Professional'naia otvetstvennost' kak sostavliaiuschaia sotsial'noy otvetstvennosti. [Professional Responsibility As a Component of Social Responsibility] // Istoricheskie, filosofskie, politicheskie i iuridicheskie nauki, kul'turologiia i iskusstvovedenie. Voprosy teorii $i$ praktiki. Tambov: Gramota, (3), 4-16, 2012.

3. Antsupov A.Ia., Shipilov A.I. Slovar' konfliktologa [Resolution Manager's Dictionary]. Saint Petersburg: Piter, 2006.

4. Bodrov V.A., Lutsenko A.G. Professional'naia otvetstvennost' kak psikhologicheskaia kategoriia sub'ekta deiatel'nosti [Professional Responsibility As a Psychological Category of a Process Owner] // Psikhologickeskie issledovaniia problemy formirovaniia lichnosti professionala. Moscow: Psychology Institute of the USSR Academy of Science, 157-167, 1991. 
5. Bol'shakova O.N. Problema formirovaniia professional'noy otvetstvennosti studentov vuza [Problem of Forming the Professional Responsibility of College Students] // Press of Herzen State Pedagogical University of Russia, (102), 24-30, 2009.

6. Bol'shaia entsiklopediia testov [Big Test Encyclopaedia]. Moscow: EKSMO, 2005.

7. Bulatnikov, I.E. Vospitatel'naia sistema obrazovatel'nogo uchrezhdeniia kak faktor razvitiia sotsial'noy i professional'noy otvetstvennosti buduschikh spetsialistov [Pedagogic System of an Education Institution as a Factor of Developing Social and Professional Responsibility of Future Specialists] // Psikhkologo-pedagogicheskiy poisk, (2), 9, 2009.

8. Bykov S.V. Sotsial'no-psikhologicheskaia reguliatsiia otvetstvennosti lichnosti [Social and Psychological Regulation of a Person's Responsibility]. Dissertation for the Degree of a Candidate of Psychology. Kazan, 2006.

9. Voropaeva T.S. Strukturnye $i$ tipologicheskie osobennosti grazhdanskoy pozitsii kak sistemoobrazuiuschego faktora aktivnosti lichnosti [Structural and Typological Peculiarities of the Civic Stance as the Core Factor of a Person's Activity]. Dissertation for the Degree of a Candidate of Psychology, Kiev, 1990.

10. Gulevich O.A. Atributsiia otvetstvennosti: chto lezhit v ocnove atributivnykh suzhdeniy? [Responsibility Attribution: What Underlies the Attributive Judgments?] // Sovremennaia sotsial'naia psikhologiia: teoreticheskie podkhody i prikladnye issledovaniia. Moscow: MPSI, 2013.

11. Dementiy L.I. Otvetstvennost' kak resurs lichnosti [Responsibility as a Resource of a Person]. Moscow: Inform-Znanie, 2005.

12. Emel'ianova T.P., Belykh T.V. Sotsial'nye predstavleniia studentov-energetikov o professional'noy otvetstvennosti [Social Idea of Energy Science Students on Professional Responsibility] // Bulletin of Institute of World Economic and Informatization, (2), 95-102, 2012.

13. Zhelaevskaia N.F. Professional'naia otvetstvennost' lichnosti kak determinanta kar'ernogo prodvizheniia [Professional Responsibility of a Person as the Determinant of Career Promotion]: Dissertation for the Degree of a Doctor of Psychology, Moscow, 2009.

14. Il'in E.P. Psikhologiia voli [Psychology of Will], Saint Petersburg: Piter, 2000.

15. Kupchenko V.E. Osobennosti kharakteristik zhiznennogo puti u lits s razlichnym tipom otvetstvennosti [Peculiarities of the Life Journey of Persons With Different Responsibility Types]: Dissertation for the Degree of a Doctor of Psychology, 2004.

16. Muzdybaev K. Otvetstvennost' lichnosti v proizvodstvennom kollektive [Responsibility of a Person in a Work Collective]. Moscow: Nauka, 1983.

17. Muzdybaev K. Perezhivanie bednosti kak sotsial'noy neudachi: atributsiia otvetstvennosti, strategii sovladaniia i indikatory deprivatsii [Experiencing Poverty as a Social Failure: Attribution of Responsibility, Strategies of Coping and Deprivation Indicators] // Sotsiologichekiy Zhurnal, (1), 5-32, 2001.

18. Mukonina M.V. Tipy professional'no otvetstvennogo otnosheniia rabotnikov opasnogo proizvodstva $v$ raznykh organizatsionno-ekonomicheskikh usloviiakh [Types of Professionally Responsible Attitude of Hazardous Industry Workers Under Different Organizational and Economic Conditions]: Dissertation for the Degree of a Candidate of Psychology. Moscow, 2002.

19. May R. Novyy vzliad na svobodu i otvetstvennost' [New View of Freedom and Responsibility] // Ekzistentsial'naia traditsiia, (2), 52, 2005. 
20. Nalchadzhian A.A. Atributsiia, dissonans i sotsial'noe poznanie [Attribution, Dissonance and Social Cognition]. Directmedia, 2013.

21. Ostasheva M.A. Diagnostika otvetstvennosti podrostkov [Teenager Responsibility Diagnostics] // Psikhologicheskie sredstva vyiavleniia osobennostey lichnostnogo razvitiia podrostkov i iunoshestva, (3), 61-69, 1990.

22. Priadein V.P. Otvetstvennost' kak predmet psikhologicheskogo issledovaniia [Responsibility as an Object of a Psychological Research]. Yekaterinburg: Ural State Pedagogical University Press, 2007.

23. Rubinshteyn S.L. Osnovy obschey psikhologii [Basics of General Psychology]. Saint Petersburg: Piter, 2011.

24. Sakharova V.G. Psikhologiia otvetstvennoski i vozmozhnosti ee issledovaniia [Psychology of Responsibility and Opportunities for Research] Press of the Humanitarian Institute of Maritime State University named after admiral G.I. Nevelskoi, (2), 191-199, 2001.

25. Solodkaia M.S. Professional'naia otvetstvennost' sub'ekta upravleniia [Professional Responsibility of a Manager] // Credo, Orenburg, (3), 17-29, 1998.

26. Fetiskin N.P., Kozlov V.V., Manuylov G.M. Diagnostika emotsional'nogo intellekta (N. Holl) [Emotional Intelligence Diagnostics (After N. Hall)] // Sotsial'no-psikhologicheskaia diagnostika razvitiia lichnosti i malykh grupp. Moscow, Institute of Psychotherapy, 57-59, 2002.

27. Chirkov A.P. Otvetstvennost'v sisteme prava [Responsibility in the Legal System]. Kaliningrad: Kaliningrad State University, 1996.

28. Shadrikov V.V. Deiatel'nost' i sposobnosti [Activity and Capabilities]. Moscow: Academia, 1994.

29. Shaldybina O.N.Vzaimosviaz'professional'noyotvetstvennostiisotsial'no-psikhologicheskikh kharakteristik lichnosti rukovoditeley (na primere rukovoditeley nizovogo zvena) [Interconnection of Professional Responsibility and Social-Psychological Characteristics of the Managers' Personalities (based on lowest level managers)]: Dissertation for the Degree of a Candidate of Psychology. Saratov, 2009.

30. Aguinis, H. (2011). Organizational responsibility: Doing good and doing well.

31. Brennan, T. A. (2002). Physicians' professional responsibility to improve the quality of care. Academic Medicine, 77(10), 973-980.

32. Crystal, N. M. (2008). Professional Responsibility: Problems of Practice and the Profession.

33. Fuller, J. B., Marler, L. E., \& Hester, K. (2006). Promoting felt responsibility for constructive change and proactive behavior: Exploring aspects of an elaborated model of work design. Journal of Organizational Behavior, 27(8), 1089-1120.

34. Helkama, K. (1981). Toward a cognitive-developmental theory of attribution of responsibility: unpublished doctoral dissertation, Helsinki University.

35. Kaiser, F. G., \& Shimoda, T. A. (1999). Responsibility as a predictor of ecological behaviour. Journal of Environmental Psychology, 19(3), 243-253.

36. Kelman, H. C., \& Hamilton, V. L. (1989). Crimes of obedience: Toward a social psychology of authority and responsibility. Yale University Press.

37. Kennett, J. (2001). Agency and responsibility: A common-sense moral psychology. Oxford University Press.

$$
-525-
$$


38. Marks, D. F. (2002). Freedom, responsibility and power: Contrasting approaches to health psychology. Journal of Health Psychology, 7(1), 5-19.

\section{Структурно-уровневые}

\section{и типологические характеристики \\ психологического аспекта \\ профессиональной ответственности работников фармацевтического производства}

Н.В. Лукьянченко, И.А. Ткаченко

Сибирский государственный технологический университет

Россия, 660049, Красноярск, пр. Мира, 82

В статье определяется актуальность исследования психологического аспекта профессиональной ответственности. Выделяются его структурнье составляющие: функииональная, в которую входят личностные характеристики, обеспечивающие реализацию ответственности, и рефлексивно-аксиологическая - понимание личностью сущуности ответственности, её субъективного иченностного основания. Приводятся даннье исследования, проведённого на базе фармацевтического производства. В исследовании определень уровни развития профессиональной ответственности: операциональный, сочиальный, личностный. Установлено, что сформированность личностного уровня развития профессиональной ответственности снижает проявление характеристик операционального и социального уровней. Выделены типологические группы респондентов, различающиеся по характеристикам психологического аспекта профессиональной ответственности. Показано, что наиболее высокие функииональные показатели профессиональной ответственности имеет группа с личностным уровнем развития профессиональной ответственности, наиболее низкие - с операциональным уровнем.

Ключевые слова: профессиональная ответственность, функциональная и рефлексивноаксиологическая составляющие психологического аспекта ответственности, эмочиональная саморегуляция, волевой самоконтроль, интернальность, уровни развития профессиональной ответственности.

Научная спещиальность: 13.00.00 - педагогические науки. 